\title{
Wartość pokarmowa wybranych mieszanek zbóż jarych z roślinami bobowatymi grubonasiennymi
}

\author{
Nutritional value of selected mixtures of spring cereals with legumes
}

Magdalena Wiśniewska ${ }^{1}$ Danuta Boros ${ }^{1 凶}$, Józef Zych²

\author{
${ }^{1}$.Samodzielna Pracownia Oceny Jakości Produktów Roślinnych, \\ Instytut Hodowli i Aklimatyzacji Roślin - Państwowy Instytut Badawczy, 05-870 Radzików, \\ ${ }^{2}$ Centralny Ośrodek Badania Odmian Roślin Uprawnych, 63-022 Słupia Wielka, \\ $\triangle$ e-mail: d.boros@ihar.edu.pl
}

\begin{abstract}
Materiał badawczy obejmował trzy mieszanki dwuskładnikowe form jarych jęczmienia i pszenżyta $\mathrm{z}$ łubinem wąskolistnym i jęczmienia $\mathrm{z}$ grochem oraz ich komponenty pochodzące $\mathrm{z}$ siewu czystego. Wartość pokarmową zbadano na podstawie składu chemicznego ziarna/nasion i wartości odżywczej białka określonej in vitro oraz bezpośrednio w układzie modelowym na szczurach. Zboża jare i rośliny bobowate grubonasienne, jak również mieszanki skomponowane z ich udziałem, różniły się istotnie pod względem zawartości składników odżywczych i antyżywieniowych. Wyniki pokazały znaczący wpływ doboru składników na wartość pokarmową mieszanek zbóż jarych z roślinami bobowatymi. Udział łubinu wąskolistnego w mieszance przyczynił się do wzrostu zawartości białka i poprawy jego jakości, ale jednocześnie zwiększył ilość włókna pokarmowego. Odnosi się to w szczególności do mieszanki zjęczmieniem. Zboża, ze względu na dużą zawartość skrobi, podwyższały wartość energetyczną mieszanki. Na podstawie wskaźników chemicznych i badań bilansowych na zwierzętach stwierdzono większą wartość odżywczą białka mieszanek zbóż z roślinami bobowatymi niż ich komponentów z siewu czystego. Mieszanka jęczmienia jarego, odmiany Radek, z grochem, odmiany Model, charakteryzowała się najlepszym składem chemicznym i najwyższą wartością odżywczą białka, określoną metodami in vitro i in vivo.
\end{abstract}

Słowa kluczowe: jęczmień jary, pszenżyto jare, groch, łubin wąskolistny, mieszanki zbożowo-bobowate, składniki odżywcze, składniki antyżywieniowe, wykorzystanie białka, szczury

\begin{abstract}
The material for the study included three two-component mixtures of spring cereals, barley and triticale with narrowleafed lupine and barley with pea, as well as their components derived from pure sowing. The nutritional value of components and mixtures was determined on the basis of the chemical composition and the biological value of protein, determined directly in the model system in rats. Spring cereals and legumes, as well as mixtures composed with their participation, differed significantly in nutrient and antinutrient content. The results showed a significant effect of the component selection on the nutritional value of cereal-legumes mixtures. The share of narrow-leafed lupine in the mixture contributed to improving the quality and concomitantly increasing the content of protein, and also of dietary fibre. This applies in particular to mixtures with barley. Cereals, due to high content of starch, increase energy value of the mixture. Based on chemical indicators and study in vivo, a greater protein nutritional value was shown for cereal-legume mixtures than their components from pure sowing. Studies have revealed that a mixture of spring barley, variety Radek, with peas, variety Model, characterized with the best chemical composition and the highest nutritional value of protein, determined in vitro and in vivo.
\end{abstract}

Keywords: spring barley, spring triticale, peas, narrow-leafed lupine, cereal-legume mixtures, nutrients, antinutrients, protein utilization, rats

\section{Wstęp}

Uprawa mieszanek roślin bobowatych ze zbożami ma długą tradycję w Polsce, chociaż na przestrzeni lat cechowała się zmienną skalą produkcji. Po dramatycznym spadku areału uprawy $\mathrm{w}$ okresie transformacji, obserwowany jest ponowny wzrost zainteresowania rolników siewem mieszanym, przede wszystkim ze względu na jego znaczenie w systemie rolnictwa zrównoważonego i ekologicznego (Kotecki, 2015). Siewy mieszane wprowadzają większą bioróżnorodność do agrosystemu. Ze względu na zróżnicowanie gatunkowe, rośliny $\mathrm{w}$ mieszance w sposób komplementarny wykorzystują zasoby siedliska, następuje ich kompensacyjny wzrost i rozwój. Różnice wynikające $\mathrm{z}$ budowy morfologicznej komponentów mieszanek, ich potencjału do pobierania wody i składników pokarmowych oraz zdolność do wiązania azotu z powietrza przez bakterie brodawkowe, żyjące na korzeniach roślin bobowatych i tworzące $\mathrm{z}$ nimi układ symbiotyczny, powodują, że mieszanki zbóż jarych z roślinami bobowatymi plonują zwykle lepiej i wierniej niż siewy czyste, zwłaszcza w nieco gorszych warunkach siedliskowych (Staniak i in., 2014; Księżak i in., 2016). W mieszankach takich 
zboża korzystają z azotu wytworzonego w glebie przez bakterie brodawkowe roślin bobowatych, co pozwala na stosowanie zmniejszonych dawek nawozów mineralnych, w porównaniu do siewu czystego. Z kolei dla roślin bobowatych, zboża stanowią roślinę podporową, odnosi się to w szczególności do mieszanki z grochem, który ma tendencję do wylegania (Staniak i in., 2014). Dodatkowo mieszanki roślin bobowatych ze zbożami są mniej podatne na zachwaszczenie i bardziej odporne na choroby oraz szkodniki, ponadto łagodzą negatywne skutki związane z kolejnym siewem zbóż na tym samy polu.

Mieszanki roślin bobowatych ze zbożami można użytkować w różny sposób (Staniak i in., 2014). Uprawiane na ziarno mają duże znaczenie w gospodarstwach zajmujących się produkcją zwierzęcą, pozwalają na wyprodukowanie paszy dostarczającej jednocześnie znacznych ilości zarówno energii oraz białka. W paszach dla zwierząt, głównym źródłem energii jest ziarno zbóż, z racji dużej zawartości skrobi, a nasiona roślin bobowatych są składnikiem wysokobiałkowym, chociaż groch wyróżnia się także ilością skrobi (Jamroz, 2013). Te dwa komponenty mieszanek różnią się znacznie pod względem zawartości podstawowych składników pokarmowych (Pastuszewska, 2013; Boros i in., 2015). Co więcej, odnotowuje się istotne zróżnicowanie odmianowe zawartości tych składników w obrębie tego samego gatunku zboża i roślin bobowatych. Nasiona roślin bobowatych mają stosunkowo wysoką (łubiny) lub bardzo wysoką (groch) zawartość lizyny w białku i stanowią dobre uzupełnienie deficytowego w ten aminokwas białka zbóż (Rakowska i in., 1978). Zboża natomiast mają znacznie więcej aminokwasów siarkowych niż białko bobowatych, które są aminokwasami ograniczającymi w tym białku (Pastuszewska, 2013). Dzięki temu poprzez wzajemne uzupełnianie się aminokwasów, białko mieszanki zbóż z roślinami bobowatymi ma lepiej zbilansowany skład aminokwasowy i w efekcie znacznie większą wartość odżywczą, niż wartość pojedynczych komponentów (Pastuszewska, 2013). Czynnikiem limitującym wykorzystanie składników pokarmowych ziarna mieszanek roślin bobowatych ze zbożami jest obecność w nich substancji antyżywieniowych, które w sposób negatywny wpływają na wskaźniki produkcyjne karmionych zwierząt. Do substancji antyżywieniowych ziarna zbóż zaliczane jest włókno pokarmowe, a zwłaszcza jego frakcja rozpuszczalna w wodzie, składająca się z arabinoksylanów i $\beta$-glukanu (Bach Knudsen, 2014). W przypad$\mathrm{ku}$ nasion roślin bobowatych grubonasiennych za niepożądane w paszy uważa się, oprócz włókna pokarmowego, także związki fenolowe, zwłaszcza taniny skondensowane, alkaloidy, fityniany i inhibitory enzymów proteolitycznych (Brenes i in., 2004). Zawartość substancji antyżywieniowych w ziarnie zbóż i nasionach roślin bobowatych, podobnie jak składników pokarmowych, jest bardzo zróżnicowana nie tylko między gatunkami, ale także w obrębie gatunków (Pastuszewska, 2013; Boros i in., 2015).

Dobierając odpowiednio komponenty do mieszanek zbóż z roślinami bobowatymi grubonasiennymi, można kształtować zarówno wysokość plonowania jak i wartość użytkową zebranych płodów. Wiąże się to $\mathrm{z}$ koniecznością sprawdzenia przydatności nowych odmian zbóż i roślin bobowatych do siewów mieszanych.

Celem badań była ocena wartości pokarmowej wybranych mieszanek jęczmienia i pszenżyta z łubinem wąskolistnym lub grochem. Mieszanki te pochodziły $\mathrm{z}$ doświadczeń wykonanych w ramach Programu Wieloletniego IHAR-PIB, w którym prace obejmowały dobór odmian zbóż i odmian roślin bobowatych do siewów mieszanych, w różnych warunkach agro - klimatycznych Polski. Badania prowadzono w porównaniu do komponentów tych mieszanek z siewu czystego.

\section{Material i Metody \\ Material badawczy}

W badaniach wykorzystano ziarno trzech mieszanek dwuskładnikowych: jęczmienia z łubinem wąskolistnym (odm. Radek/Rumba), jęczmienia z grochem (odm. Radek/Model) oraz pszenżyta z łubinem wąskolistnym (odm. Sopot/Rumba), a także ich komponentów pochodzących $\mathrm{z}$ siewu czystego. Przy wyborze odmian do siewów mieszanych brano pod uwagę pochodzenie (w pierwszej kolejności odmiany krajowe), wysokie plonowanie i zróżnicowanie odporności na choroby (COBORU, 2017). Materiał badawczy pochodził ze zbioru z 2017 roku z doświadczeń COBORU, rozlokowanych w trzech Stacjach Oceny Odmian, różniących się warunkami glebowo - klimatycznymi (Dukla, Jelenia Góra, Kościelna Wieś).

\section{Analizy chemiczne}

Analizy chemiczne wykonano w uśrednionych próbkach, uzyskanych poprzez zsypanie ziarna/ nasion każdej kombinacji mieszankowej lub komponentu w równych proporcjach wagowych, $\mathrm{z}$ każdej $\mathrm{z}$ trzech miejscowości zbioru ziarna/nasion, czyli masa uśrednionej próbki analitycznej wynosiła $750 \mathrm{~g}(250 \mathrm{~g} \times 3$ miejscowości). W tak otrzymanych 
próbkach oznaczono zawartość białka surowego, przyjmując współczynnik przeliczeniowy azotu na białko 6,25 (AOAC, 955.04), popiołu surowego (AOAC, 923.03), lipidów ogółem (Marchello i in., 1971) oraz skrobi przyswajalnej (AACC, 76-13), które po zsumowaniu stanowiły składniki odżywcze (SNC - sum of nutrients).

Skład aminokwasowy białka, $\mathrm{z}$ wyjątkiem tryptofanu, badano metodą chromatografii jonowymiennej z użyciem analizatora aminokwasów AAA 400 (INGOS, Czechy). Próby hydrolizowano $6 \mathrm{M} \mathrm{HCl} \mathrm{w} 110^{\circ} \mathrm{C}$ przez 23 godziny, z zastosowaniem wstępnego utleniania aminokwasów siarkowych kwasem nadmrówkowym (Mason i in., 1980). Wyniki podano w g na 100 g aminokwasów. W celu oszacowania wartości odżywczej białka wyliczono wskaźnik aminokwasu ograniczającego (CS, chemical score) oraz wskaźnik aminokwasów niezbędnych (EAAI, essential amino acid index), przyjmując jako wzorzec skład aminokwasowy białka wzorcowego FAO (1965) (Rakowska i in., 1978).

Włókno pokarmowe (TDF, total dietary fibre) oznaczono metodą enzymatyczno - chemiczną (AACC, 32-25), jako sumę nieskrobiowych polisacharydów (NSP, non - starch polysaccharides), oligosacharydów (RFOs, raffinose family oligosaccharides), skrobi opornej (RS, resistant starch), kwasów uronowych (UA, uronic acids) oraz ligniny.

Analizę nieskrobiowych polisacharydów wykonano metodą chromatografii gazowej (Clarus 500, firmy Perkin Elmer). Polisacharydy oznaczono jako sumę pojedynczych cukrów: ramnozy, fukozy, arabinozy, ksylozy, mannozy, galaktozy i glukozy. W pierwszym etapie procedury, na drodze hydrolizy enzymatycznej usunięto skrobię, a po odwirowaniu prób uzyskano frakcję nierozpuszczalną (I - NSP, insoluble nonstarch polysaccharides) i rozpuszczalną nieskrobiowych polisacharydów (S-NSP, soluble nonstarch polysaccharides), które poddano kwaśnej hydrolizie $\mathrm{z} 1 \mathrm{M}$ kwasem siarkowym $\left(100^{\circ} \mathrm{C}\right.$, 2h). Uzyskane monomery cukrów upochodniono do lotnych pochodnych octanu alditolu i rozdzielono w kapilarnej kolumnie kwarcowej Rtx - 225 $(0.53 \mathrm{~mm} \times 30 \mathrm{~m})$. Temperatura rozdziału cukrów $225^{\circ} \mathrm{C}$, injektora i detektora $275^{\circ} \mathrm{C}$. Jako gaz nośny wykorzystano hel.

Zawartość oligosacharydów oznaczono jako sumę: rafinozy, stachiozy i werbaskozy metodą chromatografii gazowej (Autosystem XL, Perkin Elmer, USA) według Lahuty (2018). Próby $(40-45 \mathrm{mg})$ ekstrahowano w 50\% wodnym roztworze etanolu $\left(30\right.$ minut, $\left.90^{\circ} \mathrm{C}\right)$, zawierającym wzorzec wewnętrzny - ksylitol $(100 \mu \mathrm{g})$. Wyekstrahowane cukry odwirowano $\left(20\right.$ minut, $\left.4^{\circ} \mathrm{C}, 21000 \mathrm{~g}\right)$ i $400 \mu \mathrm{l}$ homogenatu dejonizowano mieszaniną $(300 \mu 1)$ jonów Dowex - żywica jonowymienna w czasie 45 minut. Po odwirowaniu część $(200 \mu l)$ klarownego ekstraktu wysuszono (w fiolkach do chromatografii gazowej zawierających inserty) w wirówce próżniowej. Suche pozostałości prób upochodniono mieszaniną TMSI z pirydyną $(1: 1 \mathrm{v} / \mathrm{v})\left(80^{\circ} \mathrm{C}, 40\right.$ minut $) \mathrm{w}$ suchym bloku grzejnym. Uzyskane trimetylokrzemianowe pochodne cukrów rozdzielono $\mathrm{w}$ kolumnie kapilarnej ZEBRON ZB-1 $(0.25 \mathrm{~mm} \times 15 \mathrm{~m})$. Temperatura injektora $325^{\circ} \mathrm{C}$, detektora $350^{\circ} \mathrm{C}$. Kolumnę ogrzewano od $150^{\circ} \mathrm{C}$ do $350^{\circ} \mathrm{C}$ z różnym tempem wzrostu temperatury. Jako gaz nośny wykorzystano hel.

Zawartość skrobi opornej oznaczono kolorymetrycznie według AACC, 32-40. Po usunięciu skrobi przyswajalnej, skrobia oporna (RS), pozyskana w postaci osadu została rozpuszczona w roztworze $2 \mathrm{M} \mathrm{KOH}$. Następnie roztwór ten zobojętniono, a skrobia pod wpływem działania amyloglukozydazy została zhydrolizowana do glukozy. Oznaczenie glukozy wykonano z wykorzystaniem odczynnika GOPOD, zawierającego oksydazę i peroksydazę glukozową.

Zawartość kwasów uronowych została oznaczona kolorymetrycznie według Scotta (1979). Wykorzystano do tego celu 3,5-dimetylofenol, który jest wysoce selektywny w odniesieniu do pochodnych kwasów uronowych w obecności stężonego kwasu siarkowego.

Ligninę oznaczono grawimetrycznie metodą Theandera i Westerlunda (1986), jako wysuszoną $\left(105^{\circ} \mathrm{C}, 16 \mathrm{~h}\right)$ pozostałość próby, uprzednio trawioną $72 \%$ kwasem siarkowym i spopieloną $\left(550^{\circ} \mathrm{C}\right.$, 5 godzin). Zawartość procentową ligniny obliczono na podstawie ubytku wysuszonej wagi po spopieleniu próby.

Do oznaczenia całkowitej ilości związków fenolowych (TPC, total phenolic compounds), ekstrahowanych $80 \%$ metanolem, a następnie $70 \%$ acetonem, wykorzystano metodę z reagentem Folina-Ciocalteu (Singleton i Rossi, 1965), przedstawiając wyniki jako ekwiwalent miligramów kwasu galusowego (GAE) na g suchej masy próby.

Taniny skondensowane oznaczono również kolorymetrycznie, metodą wanilinową (Price i in., 1978), a wyniki przedstawiono jako ekwiwalent miligramów katechiny na g suchej masy próby. Analizę zawartości inhibitora trypsyny (TUI) wykonano metodą kolorymetryczną, $\mathrm{z}$ użyciem substratu BAPNA, według standardowej procedury Kakade i in. (1974). Pomiaru absorbancji 
w oznaczeniach kolorymetrycznych dokonano w spektrofotometrze UV-1601 (Rayleigh, UK).

\section{Doświadczenie na zwierzętach}

Procedura doświadczalna została zatwierdzona przez II Lokalną Komisję Etyczną ds. Doświadczeń na Zwierzętach w Warszawie (uchwała nr WAW2/52/2016).

Ocenę wartości odżywczej białka przeprowadzono metoda bilansową z wykorzystaniem 40 szczurów outbredowych Wistar, o średniej masie początkowej 78,30 $\pm 4 \mathrm{~g}$, podzielonych na 8 grup doświadczalnych. Doświadczenie bilansowe wykonano zgodnie z procedurą Egguma (1973), według której badane ziarno/nasiona stanowiły jedyne źródło białka w diecie, na poziomie $9,4 \% \mathrm{w}$ powietrznie suchej masie. Zwierzęta w całym okresie doświadczalnym miały stały dostęp do wody, otrzymywały dziennie $10 \mathrm{~g}$ diety pokrywającej całkowicie potrzeby energetyczne i mineralno - witaminowe rosnących szczurów. W 9-dniowym doświadczeniu cztery pierwsze dni były okresem adaptacyjnym, w którym szczury przystosowywały się do odosobnienia, topografii klatki (klatki metaboliczne Vivari, Włochy) oraz diety. Pozostałe dni były okresem bilansowym, z całkowitą kolekcją kału i moczu.

Po oznaczeniu azotu i suchej masy w kale oraz azotu w moczu, wyliczono strawność rzeczywistą białka (TPD - true protein digestibility), jego

wartość biologiczną (BV - biological value) oraz wykorzystanie netto (NPU - net protein utilization). Oznaczono także strawność suchej masy (DMD - dry matter digestibility). Ilość azotu metabolicznego w kale oraz endogennego w moczu obliczono na podstawie wzoru Lehmana i in. (1968).

\section{Analiza statystyczna}

Wszystkie analizy chemiczne wykonano w trzech powtórzeniach, a wyniki wyrażono w procentach suchej masy. Wyniki poddano ocenie statystycznej, wykorzystując do tego celu jednoczynnikową analizę wariancji według modelu efektów stałych i procedurę porównań wielokrotnych Tukeya - Kramera. Obliczenia statystyczne wykonano w programie Statistica w wersji 13.3 (TIBCO Software Inc., 2017).

\section{Wyniki i Dyskusja}

Do badań wybrano mieszanki, w których udział roślin bobowatych był najwyższy: w mieszankach $\mathrm{z}$ łubinem wąskolistnym stanowił około $23 \%$, a z grochem $34 \%$. W materiale przygotowanym do siewu mieszanego udział zbóż wynosił $40 \%$ obsady w siewie czystym, a roślin bobowatych 60\% (COBORU, 2017). Mniejszy udział nasion bobowatych w mieszance w momencie zbioru w porównaniu $\mathrm{z}$ ich udziałem w materiale siewnym wynika $\mathrm{z}$ różnicy potencjału plonowania

Tabela 1

Table 1

Składniki odżywcze w ziarnie mieszanek zbożowo-bobowatych oraz ich komponentów z siewu czystego (\% s.m.)

Nutrient content in cereal mixtures with legumes and their pure components (\% d.m.)

\begin{tabular}{|c|c|c|c|c|c|}
\hline $\begin{array}{l}\text { Składnik / mieszanka } \\
\text { Component / mixture }\end{array}$ & $\begin{array}{l}\text { Białko surowe } \\
\text { Crude protein }\end{array}$ & $\begin{array}{l}\text { Skrobia } \\
\text { Starch }\end{array}$ & $\begin{array}{l}\text { Lipidy } \\
\text { Lipids }\end{array}$ & $\begin{array}{l}\text { Popiół surowy } \\
\text { Crude ash }\end{array}$ & $\mathrm{SNC}^{*}$ \\
\hline $\begin{array}{c}\text { Jęczmień jary / Spring barley } \\
\text { Radek }\end{array}$ & $9,7^{g}$ & $56,6^{b}$ & $2,8^{d e}$ & $2,5^{d}$ & $71,6^{b}$ \\
\hline $\begin{array}{c}\text { Pszenżyto jare / Spring triticale } \\
\text { Sopot }\end{array}$ & $10,1^{f}$ & $63,9^{a}$ & $2,5^{e}$ & $1,9^{e}$ & $78,3^{a}$ \\
\hline $\begin{array}{l}\text { Lubin wąskolistny / Narrow-leaved lupine } \\
\qquad \text { Rumba }\end{array}$ & $31,3^{a}$ & $0,7^{\mathrm{g}}$ & $7,8^{a}$ & $4,4^{a}$ & $44,2^{d}$ \\
\hline $\begin{array}{l}\text { Groch / Peas } \\
\text { Model }\end{array}$ & $20,8^{b}$ & $44,8^{e}$ & $3,2^{c}$ & $3,3^{b}$ & $72,2^{b}$ \\
\hline $\begin{array}{c}\text { Mieszanka jęczmienia z łubinem / Mixture of } \\
\text { barley and lupine (Radek/Rumba) }\end{array}$ & $16,0^{\mathrm{d}}$ & $40,4^{f}$ & $3,9^{b}$ & $2,8^{c}$ & $63,1^{c}$ \\
\hline $\begin{array}{l}\text { Mieszanka pszenżyta z łubinem / Mixture of } \\
\text { triticale and lupines (Sopot/Rumba) }\end{array}$ & $18,2^{\mathrm{c}}$ & $47,8^{d}$ & $3,6^{b}$ & $2,6^{d}$ & $72,2^{b}$ \\
\hline $\begin{array}{c}\text { Mieszanka jęczmienia z grochem / Mixture of } \\
\text { barley and peas (Radek/Model) }\end{array}$ & $14,9^{\mathrm{e}}$ & $51,1^{c}$ & $3,1^{c d}$ & $2,9^{c}$ & $71,9^{b}$ \\
\hline Statystyka F / Statistics F & 65863 & 1918,35 & 630,86 & 304,44 & 594,5 \\
\hline Wartość p / p - value & 0,000 & 0,000 & 0,000 & 0,000 & 0,000 \\
\hline
\end{tabular}

*SNC-suma składników odżywczych / SNC-sum of nutrients

** Wartości w kolumnach opatrzone różnymi literami różnia się istotnie przy $p \leq 0,05$ / Values in the columns with different letters differ significantly at $p \leq 0.05$ 
zbóż i roślin bobowatych, jak również mógł być spowodowany wypadaniem roślin bobowatych na skutek konkurencyjności roślin w łanie (Staniak i in., 2014).

Zboża jare i rośliny bobowate, jak również mieszanki skomponowane $\mathrm{z}$ ich udziałem różniły się istotnie pod względem zawartości składników odżywczych i antyżywieniowych (Tabele 1-5). Różnice te wynikają przede wszystkim ze zróżnicowania gatunkowego użytych zbóż jarych (Boros $i$ in. 2015) i roślin bobowatych (Grela i in., 2017). W odniesieniu do składników odżywczych ziarno jęczmienia odmiany Radek i pszenżyta odmiany Sopot różniło się nieznacznie, choć istotnie w zawartości: białka $(9,7 \%$ vs. 10,1\%), lipidów (2,8\% vs. $2,5 \%)$ i popiołu (2,5\% vs.1,9\%) (Tab. 1$)$. Większą istotną różnicę między ziarnem badanych odmian jęczmienia oraz pszenżyta stwierdzono w ilości skrobi $(56,5 \%$ vs. $63,9 \%)$ i w efekcie sumy składników odżywczych $(71,6 \%$ vs. $78,3 \%)$. W przeciwieństwie do ziarna zbóż, nasiona łubinu wąskolistnego i grochu były znacznie bardziej zróżnicowane pod względem zawartości składników odżywczych, w szczególności białka, skrobi i lipidów. Nasiona łubinu wąskolistnego odmiany Rumba, charakteryzowały się o $50 \%$ większą ilością białka (31,3\%), niż nasiona grochu odmiany Model (20,8\%). Wartości mieściły się w zakresach podanych dla tych dwóch gatunków roślin bobowatych przez innych autorów (Grela i in., 2017) i były w sposób istotny zależne od roku uprawy oraz w przypadku łubinu, także od typu odmiany i terminu siewu (Kotlarz i in., 2011). Pod względem zawartości skrobi rośliny bobowate grubonasienne cechuje duże zróżnicowanie. W nasionach łubinu zawartość skrobi jest niewielka 0,6\%-0,8\% (Maharjan i in., 2019), podczas gdy w nasionach grochu bardzo duża 38,6\% - 45,3\% (Hejdysz i in., 2015). Podobne zróżnicowanie zawartości skrobi uzyskano w niniejszej pracy. W nasionach łubinu wąskolistnego odmiany Rumba wykazano 0,7\%, a w nasionach grochu odmiany Model 44,8\% skrobi. Nasiona łubinu wąskolistnego wyróżniały się natomiast ilością lipidów, która była prawie 2,5 razy większa niż w nasionach grochu (7,8\% vs. 3,2\%). W badaniach Kaczmarka i in. (2014) oraz Hejdysza $\mathrm{i}$ in. (2015) wykazano jeszcze większe zróżnicowanie między łubinem wąskolistnym a grochem w zawartości składnika wysokoenergetycznego, odpowiednio 5,8\% i 1,3\%, mierzonego jako ekstrakt eterowy. Nasiona bobowatych różniły się ponadto zawartością popiołu surowego, łubin wąskolistny zawierał tego składnika o 33\% więcej niż groch. Zróżnicowanie ilościowe składników odżywczych w łubinie wąskolistnym i grochu, głównie skrobi, miało istotny wpływ na ogólną zawartość składników odżywczych. $\mathrm{Z}$ tego względu nasiona łubinu wąskolistnego miały najmniej składników odżywczych ogółem $(44,2 \%)$, podczas gdy w grochu ich ilość była porównywalna $(72,2 \%)$ do ilości w ziarnie jęczmienia. Obecność nasion bobowatych w mieszance ze zbożami spowodowała wysoce istotny wzrost zawartości białka. Było to szczególnie widoczne w mieszankach $\mathrm{z}$ łubinem wąskolistnym, w których stwierdzono zwiększenie ilości białka w ziarnie mieszanki z jęczmieniem o ponad 1,3 jednostki procentowe, a $\mathrm{w}$ ziarnie mieszanki z pszenżytem o 3,2 jednostki procentowe, niż wynikałoby to $\mathrm{z}$ wyliczenia $\mathrm{z}$ zawartości w komponentach i ich udziału w mieszankach. Prawdopodobnie rośliny jęczmienia i pszenżyta $\mathrm{w}$ zasiewach mieszanych, mogły korzystać z większej ilości azotu w glebie, zsyntetyzowanego przez bakterie symbiotyczne łubinu wąskolistnego. W literaturze dostępne są wyniki prac wskazujące na wzrost zawartości białka ogólnego w ziarnie zbóż pod wpływem zwiększonego nawożenia azotem (Biel, Jaroszewska, 2016).

Wartość odżywcza białka zależy w pierwszym rzędzie od zawartości aminokwasów, w szczególności aminokwasów egzogennych oraz ich wzajemnych proporcji (Rakowska i in., 1978). Ziarno poszczególnych gatunków zbóż i nasiona roślin bobowatych różniły się istotnie składem aminokwasowym białka (Tab. 2). W odniesieniu do sumy aminokwasów egzogennych zróżnicowanie ich zawartości obserwowano w zakresie od 34,4g/100g aminokwasów w białku pszenżyta odmiany Sopot do 44,4g/100g aminokwasów w białku grochu odmiany Model. Białko zbóż charakteryzowało się istotnie niższą zawartością omawianych aminokwasów w porównaniu do białka nasion roślin bobowatych (średnio o 15\%). W przypadku pojedynczych aminokwasów zróżnicowanie to obserwowano przede wszystkim wodniesieniu do zawartości lizyny, której największą istotnie koncentrację wykazano w białku grochu $(7,7 \mathrm{~g} / 100 \mathrm{~g}$ aminokwasów), a następnie w łubinie wąskolistnym $(4,7 \mathrm{~g} / 100 \mathrm{~g}$ aminokwasów). Białko zbóż miało istotnie mniej tego aminokwasu w porównaniu do białka roślin bobowatych, choć w jęczmieniu ilość lizyny była istotnie większa $(4,0 \mathrm{~g} / 100 \mathrm{~g}$ aminokwasów) niż w pszenżycie $(3,3 \mathrm{~g} / 100 \mathrm{~g}$ aminokwasów). Mniejsze różnice stwierdzono w zawartości aminokwasów siarkowych, których istotnie więcej było w białku jęczmienia $(3,8 \mathrm{~g} / 100 \mathrm{~g}$ aminokwasów) i pszenżyta $(3,7 \mathrm{~g} / 100 \mathrm{~g}$ aminokwasów\%), niż w białku grochu (2,6g/100g aminokwasów), 
a w szczególności łubinu wąskolistnego $(2,2 \mathrm{~g} / 100 \mathrm{~g}$ aminokwasów). Ilość treoniny była istotnie największa w białku grochu $(3,6 \mathrm{~g} / 100 \mathrm{~g}$ aminokwasów), następnie w białku łubinu i jęczmienia $(3,0 \mathrm{~g} / 100 \mathrm{~g}$ aminokwasów), a najmniejsza w białku pszenżyta (2,6g/100g aminokwasów). Zróżnicowanie profilu aminokwasowego białka zbóż i roślin bobowatych wpłynęło na zróżnicowanie ilościowe aminokwasów zawartych w białku mieszanek. Największą istotnie ilością lizyny i treoniny cechowało się białko mieszanki jęczmienia $\mathrm{z}$ grochem (odpowiednio 5,3g/100g aminokwasów, 3,2g/100g aminokwasów). W odniesieniu do zawartości aminokwasów siarkowych nie zaobserwowano istotnych różnic pomiędzy mieszankami, a ich białko zawierało średnio 3,6g/100g aminokwasów siarkowych.

Spośród komponentów mieszanek, pochodzących z siewu czystego, ziarno jęczmienia charakteryzowało się najlepszą wartością odżywczą białka, na co wskazywała wartość wskaźnika aminokwasu ograniczającego $(\mathrm{CS}=58)$ oraz zintegrowanego wskaźnika aminokwasów egzogennych $($ EEAI $=77)$. Największą wartość EEAI stwierdzono jednakże u grochu (82), co wskazuje na wysoką jakość tego białka, wyższą niż pozostałych komponentów mieszanek. $\mathrm{Z}$ tego względu mieszanka jęczmienia jarego z grochem miała najlepiej zbilansowany skład aminokwasowy białka i najwyższe wskaźniki chemiczne określające jego wartość odżywczą. W zbożach, jak również $\mathrm{w}$ mieszankach $\mathrm{z}$ łubinem wąskolistnym aminokwasem ograniczającym wykorzystanie białka była lizyna, zaś w odniesieniu do roślin bobowatych i mieszanki z grochem suma metioniny i cystyny. Lizynę, jako aminokwas najczęściej deficytowy w białku jęczmienia i pszenżyta wskazywali też inni autorzy (Boros i in., 2010; Kowieska i in., 2011), a aminokwasy siarkowe w białku łubinu wąskolistnego i grochu (Kotlarz i in., 2011; Pastuszewska, 2013; Koivunen i in., 2016; Grela i in., 2017). Duża koncentracja lizyny w białku jęczmienia i grochu wpłynęła na zwiększenie jej zawartości w białku mieszanki do wysokości $76 \%$ białka wzorca, stąd aminokwasami ograniczającymi $\mathrm{w}$ tej mieszance były metionina i cystyna $(C S=62)$. Podsumowując, wartość odżywcza białka mieszanek jęczmienia i pszenżyta $\mathrm{z}$ łubinem wąskolistnym oraz jęczmienia $z$ grochem, oceniona na podstawie wskaźników chemicznych, była wyższa niż ich komponentów z siewu czystego.

Tabela 2

Table 2

Zawartość ograniczających aminokwasów egzogennych (g/100g aminokwasów) i wskaźniki jakości białka ziarna mieszanek zbożowo-bobowatych oraz ich komponentów z siewu

Content of limiting essential amino acids and qualitative protein indices in cereal mixtures with legumes and their pure components (g/100g amino acids)

\begin{tabular}{|c|c|c|c|c|c|c|}
\hline $\begin{array}{l}\text { Zboże } \\
\text { Cereal }\end{array}$ & Lys* & Thr* & Met + Cys* & $\begin{array}{c}\text { Suma EAA } \\
\text { Sum } \\
\text { of EAA* }\end{array}$ & $\mathrm{CS}^{*}$ & EAAI* \\
\hline $\begin{array}{c}\text { Jęczmień jary/Spring barley } \\
\text { Radek }\end{array}$ & $4,03^{d}$ & $3,02^{b}$ & $3,80^{a}$ & $38,0^{c}$ & 58 lys & 77 \\
\hline $\begin{array}{c}\text { Pszenżyto jare/Spring triticale } \\
\text { Sopot }\end{array}$ & $3,27^{e}$ & $2,57^{c}$ & $3,73^{a}$ & $34,4^{d}$ & 47 lys & 69 \\
\hline $\begin{array}{l}\text { Łubin wąskolistny/Narrow-leaved lupine } \\
\qquad R u m b a\end{array}$ & $4,65^{c}$ & $3,01^{c}$ & $2,23^{c}$ & $40,8^{b}$ & 39 met + cys & 71 \\
\hline $\begin{array}{l}\text { Groch/Peas } \\
\text { Model }\end{array}$ & $7,66^{a}$ & $3,61^{a}$ & $2,56^{b}$ & $44,4^{a}$ & 45 met + cys & 82 \\
\hline $\begin{array}{l}\text { Mieszanka jęczmienia z łubinem/Mixture } \\
\text { of barley and lupine (Radek/Rumba) }\end{array}$ & $4,05^{d}$ & $3,07^{b}$ & $3,56^{a}$ & $37,9^{c}$ & 58 lys & 75 \\
\hline $\begin{array}{l}\text { Mieszanka pszenżyta z łubinem/Mixture } \\
\text { of triticale and lupines (Sopot/Rumba) }\end{array}$ & $3,44^{e}$ & $2,58^{c}$ & $3,71^{a}$ & $34,9^{d}$ & 49 lys & 69 \\
\hline $\begin{array}{l}\text { Mieszanka jęczmienia z grochem/Mixtu- } \\
\text { re of barley and peas (Radek/Model) }\end{array}$ & $5,29^{b}$ & $3,23^{a b}$ & $3,52^{a}$ & $40,0^{\mathrm{b}}$ & 62 met $+c y s$ & 78 \\
\hline Statystyka F/Statistics F & 523,03 & 28,69 & 93,22 & 186,5 & - & - \\
\hline Wartość p/p - value & $4,03^{d}$ & $3,02^{b}$ & $3,80^{a}$ & $38,0^{c}$ & - & - \\
\hline
\end{tabular}

*Lys - lizyna/lysine; Thr-treonina/threonine; Met-metionina/methionine; Cys-cysteine/cysteine; EAA-aminokwasy egzogennelessential amino acids; CS - wskaźnik aminokwasu ograniczającego/chemical score; EAAI-indeks aminokwasów ograniczajacych/the essential amino acid index

** Wartości $w$ kolumnach opatrzone różnymi literami różnia się istotnie przy $p \leq 0,05 /$ Values in the columns with different letters differ significantly at $p \leq 0.05$ 
Ziarno zbóż i nasiona roślin bobowatych różniły się istotnie pod względem ilości, jak również składu włókna pokarmowego (TDF), którego zawartość mieściła się w zakresie od 13,0\% w ziarnie pszenżyta do $55,2 \% \mathrm{w}$ nasionach łubinu (Tab. 3). Ziarno jęczmienia miało o około $35 \%$ więcej TDF niż ziarno pszenżyta, a nasiona grochu o ponad połowę mniej niż nasiona łubinu. Zbliżonym poziomem TDF, w ilości $21,1 \%$ i $20,3 \%$ charakteryzowały się mieszanki: łubinu wąskolistnego $\mathrm{z}$ pszenżytem $\mathrm{i}$ jęczmienia $\mathrm{z}$ grochem, a istotnie więcej włókna wykazano $(26,0 \%) \mathrm{w}$ mieszance jęczmienia z łubinem. Podobne różnice w ilości włókna pokarmowego $\mathrm{w}$ ziarnie jarych form jęczmienia i pszenżyta oraz nasion łubinu wąskolistnego i grochu były uzyskane przez innych autorów, niezależnie od ich genetycznego pochodzenia i miejsca produkcji (de Almeida Costa i in., 2006; Boros i in., 2015; Fraś $\mathrm{i}$ in., 2016). W niniejszych badaniach, nieskrobiowe polisacharydy, główny składnik włókna pokarmowego, występowały w największej ilości w nasionach łubinu wąskolistnego (42,7\%), stanowiąc ponad $77 \%$ jego całkowitej zawartości. Pozostałą część TDF w nasionach łubinu tworzyły oligosacharydy i kwasy uronowe, w ilości odpowiednio $7,0 \%$ i 3,8\%. Nasiona grochu, w porównaniu z łubinem, były znacznie uboższe we włókno pokarmowe $(27,0 \%)$, które w około 44\% składało się z NSP, a w $25 \%$ z oligosacharydów. We włóknie pokarmowym nasion roślin bobowatych znaczący udział miały również lignina (11\%) oraz kwasy uronowe i skrobia oporna (po około 10\%). W odróżnieniu od nasion roślin bobowatych, ziarno zbóż miało istotnie mniej TDF, w skład którego poza NSP wchodziła jeszcze lignina. W przypadku pszenżyta, suma NSP i ligniny stanowiła $89 \%$, zaś jęczmienia 93\% ogólnej zawartości włókna pokarmowego, z czego udział NSP w obu gatunkach wynosił średnio 68\%. Zróżnicowanie komponentów mieszanek pod względem ogólnej zawartości TDF, jak i jego składników, miało istotny wpływ na ich zawartość w mieszankach zbożowo - bobowatych. Odnosi się to w szczególności do zawartości NSP, kwasów uronowych i oligosacharydów, których poziom był uwarunkowany udziałem grochu bądź łubinu $\mathrm{w}$ mieszance. Mieszanka jęczmienia $\mathrm{z}$ grochem

Tabela 3

Table 3

Zawartość składników włókna pokarmowego (\% s.m.) w ziarnie mieszanek zbożowo-bobowatych oraz ich komponentów z siewu czystego

Content of dietary fibre constituents (\% d.m.) in cereal mixtures with legumes and their pure components

\begin{tabular}{|c|c|c|c|c|c|c|c|c|}
\hline $\begin{array}{l}\text { Zboże } \\
\text { Cereal }\end{array}$ & I-NSP* & S-NSP* & NSP* & $\begin{array}{l}\text { Lignina } \\
\text { Lignin }\end{array}$ & $\mathrm{UA}^{*}$ & RS* & RFOs* & $\mathrm{TDF}^{*}$ \\
\hline $\begin{array}{l}\text { Jęczmień jary/Spring barley } \\
\text { Radek }\end{array}$ & $7,7^{e f}$ & $4,2^{a}$ & $11,9^{d}$ & $4,4 a$ & $0,3^{e}$ & $0,4^{c}$ & $0,6^{d}$ & $17,5^{d}$ \\
\hline $\begin{array}{c}\text { Pszenżyto jare/Spring triticale } \\
\text { Sopot }\end{array}$ & $6,5^{f}$ & $2,5^{c}$ & $9,0^{e}$ & $2,6^{d}$ & $0,3^{e}$ & $0,3^{c}$ & $0,7^{d}$ & $13,0^{e}$ \\
\hline $\begin{array}{l}\text { Łubin wąskolistny/Narrow-leaved lupine } \\
\text { Rumba }\end{array}$ & $39,7^{a}$ & $3,0^{b}$ & $42,7^{a}$ & $1,7^{e}$ & $3,8^{a}$ & $0,0^{e}$ & $7,0^{a}$ & $55,2^{a}$ \\
\hline $\begin{array}{l}\text { Groch/Peas } \\
\text { Model }\end{array}$ & $10,6^{c d}$ & $1,4^{d}$ & $12,0^{d}$ & $3,0^{c}$ & $2,6^{b}$ & $2,6^{a}$ & $6,8^{a}$ & $27,0^{b}$ \\
\hline $\begin{array}{l}\text { Mieszanka jęczmienia z tubinem/Mixture } \\
\text { of barley and lupine (Radek/Rumba) }\end{array}$ & $15,2^{b}$ & $4,1^{a}$ & $19,3^{b}$ & $3,1^{c}$ & $1,4^{c}$ & $0,4^{c}$ & $1,8^{c}$ & $26,0^{b}$ \\
\hline $\begin{array}{l}\text { Mieszanka pszenżyta z łubinem/Mixture of triti- } \\
\text { cale and lupines (Sopot/Rumba) }\end{array}$ & $12,4^{c}$ & $3,0^{b}$ & $15,4^{c}$ & $2,6^{d}$ & $1,2^{d}$ & $0,3^{d}$ & $1,7^{c}$ & $21,1^{c}$ \\
\hline $\begin{array}{l}\text { Mieszanka jęczmienia z grochem/Mixture } \\
\text { of barley and peas (Radek/Model) }\end{array}$ & $8,9^{d e}$ & $2,8^{b c}$ & $11,8^{d}$ & $3,8^{b}$ & $1,1^{d}$ & $1,1^{b}$ & $2,5^{b}$ & $20,3^{c}$ \\
\hline Statystyka F/Statistics F & 671,064 & 131,672 & 687,303 & 549,77 & 1350,62 & 4316,90 & 2632,14 & 469,89 \\
\hline Wartość p/p - value & 0,000 & 0,000 & 0,000 & 0,000 & 0,000 & 0,00 & 0,00 & 0,000 \\
\hline
\end{tabular}

*I-NSP - nierozpuszczalne nieskrobiowe polisacharydy/insoluble nonstarch polysaccharides; S-NSP - rozpuszczalne nieskrobiowe polisacharydy/soluble nonstarch polysaccharides; NSP - nieskrobiowe polisacharydy/nonstarch polysacchrides; UA - kwasy uronowe/uronic acids; RS - skrobia oporna/resistant starch; RFOs - cukry z rodziny rafinozy/raffinose family oligosaccharides; TDF - włókno pokarmowe ogółem/total dietary fibre

** Wartości w kolumnach opatrzone różnymi literami różnia się istotnie przy $p \leq 0,05 /$ Values in the columns with different letters differ significantly at $p \leq 0.05$ 
miała istotnie więcej oligosacharydów $(2,5 \%)$ i skrobi opornej $(1,1 \%)$ niż dwie mieszanki z łubinem wąskolistnym, odpowiednio średnio o $30 \%$ i $68 \%$. Jednocześnie mieszanka ta miała mniejszą ilość NSP, które stanowiły 58,1\% włókna mieszanki, w tym blisko $24 \%$ występowało w formie rozpuszczalnej. Z kolei w mieszankach z łubinem istotnie mniejszą zawartością NSP $(15,4 \%)$ charakteryzowała się ta $\mathrm{z}$ pszenżytem, a w mieszance $\mathrm{z}$ jęczmieniem było tych związków o $25 \%$ więcej. Wysoka zawartość włókna w nasionach łubinu wąskolistnego jest uznawana za główny czynnik ograniczający jego większe stosowanie w żywieniu zwierząt monogastrycznych (Kaczmarek i in. 2014).

Antyodżywczy charakter wykazują również związki fenolowe, wśród których zdecydowanie niekorzystny wpływ na efekty produkcyjne zwierząt mają taniny. Związki te znajdujące się głównie $\mathrm{w}$ łusce nasion, tworzą $\mathrm{w}$ przewodzie pokarmowym niestrawne kompleksy z białkami, prowadząc do zmniejszenia retencji białka (Brenes i in., 2004). Według Brenes i in. (2004) strawność białka jest odwrotnie proporcjonalna do zawartości tanin w paszy. Związki te nadają ponadto paszy cierpki i gorzki smak, przez co jej spożycie maleje. W badanym materiale ogólna zawartość związków fenolowych mieściła się $\mathrm{w}$ zakresie od $1,2 \mathrm{mg} / \mathrm{g}$ do $3,4 \mathrm{mg} / \mathrm{g}$, zaś tanin od $0,0 \mathrm{mg}$ do $0,3 \mathrm{mg} / \mathrm{g}$
(Tab. 4). Największą ilość związków fenolowych oznaczono w nasionach grochu $(3,4 \mathrm{mg} / \mathrm{g})$ oraz ziarnie jęczmienia $(2,6 \mathrm{mg} / \mathrm{g})$. Jednocześnie, w genotypach tych, zawartość tanin skondensowanych była najwyższa i wynosiła, odpowiednio $0,19 \mathrm{mg} / \mathrm{g}$ w grochu i $0,30 \mathrm{mg} / \mathrm{g}$ w jęczmieniu. Podobne zawartości tanin, dla tych dwóch gatunków roślin uzyskali Xu i in. (2007) oraz Hejdysz $\mathrm{i}$ in., (2015), odpowiednio w zakresie $0,0-1,71 \mathrm{mg} / \mathrm{g}$ dla grochu oraz $0,41-0,99 \mathrm{mg} / \mathrm{g}$ dla jęczmienia. W odniesieniu do zawartości TPC, ilości uzyskane w nasionach łubinu oraz ziarnie jęczmienia i pszenżyta były zbieżne $\mathrm{z}$ wynikami prezentowanymi w innych pracach (Zhu i in., 2015; Fraś i in., 2016; Król i in., 2018). Ilość związków fenolowych, oznaczona w grochu była znacznie wyższa od wartości uzyskanych przez innych autorów (Xu i in., 2007; Piecyk i in., 2012), co prawdopodobnie wynika ze zróżnicowania odmian w badaniach, a także odmiennych warunków środowiska produkcji nasion. Zgodnie $\mathrm{z}$ doniesieniem Wang $\mathrm{i}$ in. (1998), zawartość związków fenolowych w nasionach grochu $\mathrm{w}$ ponad 30\% determinuje odmiana, w $18 \%$ środowisko, a pozostałe $52 \%$ podlega interakcjom środowiskowo - genotypowym. Zróżnicowanie zawartości związków fenolowych w ziarnie zbóż i nasionach roślin bobowatych, uprawianych w siewie czystym skutkowało istotnym ich

Tabela 4

Table 4

Zawartość związków fenolowych (TPC) oraz inhibitora trypsyny (TUI) w ziarnie mieszanek zbożowo-bobowatych oraz ich komponentów z siewu czystego

Content of phenolic compounds and trypsin inhibitor in cereal mixtures with legumes and their pure components

\begin{tabular}{|c|c|c|c|}
\hline $\begin{array}{l}\text { Zboże } \\
\text { Cereal }\end{array}$ & ТPC & $\begin{array}{c}\text { Taniny } \\
\text { Tannins }\end{array}$ & TUI \\
\hline $\begin{array}{l}\text { Jęczmień jary/Spring barley } \\
\text { Radek }\end{array}$ & $2,6^{b}$ & $0,30^{a}$ & $0,9^{b}$ \\
\hline $\begin{array}{c}\text { Pszenżyto jare/Spring triticale } \\
\text { Sopot }\end{array}$ & $1,2^{f}$ & $0,03^{c}$ & $0,5^{d}$ \\
\hline $\begin{array}{l}\text { Łubin wąskolistny/Narrow-leaved lupine } \\
\text { Rumba }\end{array}$ & $2,0^{d}$ & $0,00^{c}$ & $0,1^{e}$ \\
\hline $\begin{array}{l}\text { Groch/Peas } \\
\text { Model }\end{array}$ & $3,4^{a}$ & $0,19^{b}$ & $1,1^{a}$ \\
\hline $\begin{array}{c}\text { Mieszanka jęczmienia } \mathrm{z} \text { fubinem/Mixture of barley } \\
\text { and lupine (Radek/Rumba) }\end{array}$ & $2,4^{c}$ & $0,18^{b}$ & $0,7^{c}$ \\
\hline $\begin{array}{c}\text { Mieszanka pszenżyta z lubinem/Mixture of triticale } \\
\text { and lupines (Sopot/Rumba) }\end{array}$ & $1,6^{e}$ & $0,00^{c}$ & $0,5^{d}$ \\
\hline $\begin{array}{l}\text { Mieszanka jęczmienia z grochem/Mixture of barley } \\
\text { and peas (Radek/Model) }\end{array}$ & $2,4^{c}$ & $0,20^{b}$ & $1,0^{a}$ \\
\hline Statystyka F/Statistics F & 353,69 & 352,911 & 620,59 \\
\hline Wartość p/p - value & 0,000 & 0,000 & 0,000 \\
\hline
\end{tabular}

*TPC - związk fenolowe ogótem/total phenolic compounds; TUI - inhibitor trypsyny/trypsin unit inhibitor

** Wartości w kolumnach opatrzone różnymi literami różniq się istotnie przy $p \leq 0,05 /$ Values in the columns with different letters differ significantly at $p \leq 0.05$ 
zróżnicowaniem w mieszankach zbożowo - bobowatych. Ilość TPC w obu mieszankach z jęczmieniem była istotnie większa (średnio o $33 \%$ ) niż w mieszance pszenżyta $\mathrm{z}$ łubinem. $Z$ kolei ilości tanin w ziarnie mieszanek z jęczmieniem były zbliżone (średnio $0,19 \mathrm{mg} / \mathrm{g}$ ), podczas gdy w mieszance pszenżyta $\mathrm{z}$ łubinem nie stwierdzono ich obecności. W niniejszej pracy oznaczono także zawartość inhibitora trypsyny (TUI), który należy do inhibitorów z rodziny Bowmana - Birka. Działanie negatywne tego inhibitora (TUI) polega na hamowaniu aktywności enzymów proteolitycznych trzustki, trypsyny i chymotrypsyny, poprzez tworzenie z nimi nieaktywnych kompleksów. Długotrwałe podawanie paszy z TUI prowadzi ponadto do hypertrofii samego gruczołu trzustkowego oraz zwiększenia deficytu aminokwasów siarkowych (Winiarska-Mieczan, 2007). Badany materiał charakteryzował się istotnym zróżnicowaniem TUI zarówno w obrębie komponentów mieszanek, jak i samych mieszanek, pomimo niewielkiej jego zawartości. Spośród komponentów uprawianych w siewie czystym największą wartością TUI cechowały się nasiona grochu $(1,1 \mathrm{mg} / \mathrm{g})$ oraz ziarno jęczmienia $(0,9 \mathrm{mg} / \mathrm{g})$, zaś najmniejszą nasiona łubinu $(0,1 \mathrm{mg} / \mathrm{g})$ i pszenżyta $(0,5 \mathrm{mg} / \mathrm{g})$. Zróżnicowanie mieszanek pod względem TUI uwarunkowane było składem gatunkowym mieszanek. Największą ilość TUI stwierdzono $\mathrm{w}$ ziarnie mieszanki jęczmienia z grochem $(1,1 \mathrm{mg} / \mathrm{g})$, następnie jęczmienia $\mathrm{z}$ łubinem $(0,9 \mathrm{mg} / \mathrm{g})$, a najmniejszą w ziarnie pszenżyta $z$ lubinem $(0,5 \mathrm{mg} / \mathrm{g})$.

Zróżnicowanie składu chemicznego oraz profilu aminokwasowego białka ziarna jęczmienia i pszenżyta oraz nasion łubinu wąskolistnego $\mathrm{i}$ grochu, a $\mathrm{w}$ efekcie mieszanek skomponowanych z ich działem, znalazło swoje odzwierciedlenie w zróżnicowaniu wskaźników jakości białka uzyskanych w doświadczeniu bilansowym na szczurach (Tab. 5). Największym

Tabela 5

Table 5

Wskaźniki strawności suchej masy (DMD) i białka (TPD) oraz jego przyswajalności (BV) i wykorzystania netto (NPU) mieszanek zbożowo-bobowatych i ich komponentów

Indicators of digestibility of dry matter (DMD) and protein (TPD) and their bioavailability (BV) and net utilization (NPU) of cereal-legume mixtures and their pure components

\begin{tabular}{|c|c|c|c|c|c|c|c|c|}
\hline Diety/Diets & \multicolumn{2}{|c|}{ TPD } & \multicolumn{2}{|c|}{ BV } & \multicolumn{2}{|c|}{ NPU } & \multicolumn{2}{|c|}{ DMD } \\
\hline \multicolumn{9}{|c|}{ Dieta kontrolna/Control diet } \\
\hline $\begin{array}{l}\text { Kazeina } \\
\text { Casein }\end{array}$ & $100,0^{\mathrm{a}}$ & $\pm 0,7$ & $91,9^{\mathrm{a}}$ & $\pm 1,7$ & $92,2^{\mathrm{a}}$ & $\pm 2,2$ & $92,5^{\mathrm{a}}$ & $\pm 0,2$ \\
\hline \multicolumn{9}{|c|}{ Diety doświadczalna/Experimental diets } \\
\hline $\begin{array}{c}\text { Jęczmień jary/Spring barley } \\
\text { Radek }\end{array}$ & $84,8^{\mathrm{d}}$ & $\pm 2,5$ & $92,6^{\mathrm{a}}$ & $\pm 1,6$ & $78,5^{\mathrm{b}}$ & $\pm 1,3$ & $84,2^{\mathrm{e}}$ & $\pm 1,2$ \\
\hline $\begin{array}{c}\text { Pszenżyto jare/Spring triticale } \\
\text { Sopot }\end{array}$ & $91,9^{\mathrm{b}}$ & $\pm 1,2$ & $81,8^{\mathrm{b}}$ & $\pm 1,5$ & $75,1^{\mathrm{b}}$ & $\pm 1,6$ & $89,9^{\mathrm{c}}$ & $\pm 0,5$ \\
\hline $\begin{array}{l}\text { Łubin wąskolistny/Narrow-leaved } \\
\text { lupine } \\
\text { Rumba }\end{array}$ & $90,2^{\mathrm{bc}}$ & $\pm 2,9$ & $64,2^{\mathrm{e}}$ & $\pm 3,1$ & $57,8^{\mathrm{f}}$ & $\pm 2,0$ & $91,9^{\mathrm{ab}}$ & $\pm 1,6$ \\
\hline $\begin{array}{c}\text { Groch/peas } \\
\text { Model }\end{array}$ & $84,3^{\mathrm{d}}$ & $\pm 2,2$ & $73,6^{\mathrm{cd}}$ & $\pm 4,2$ & $62,1^{\text {ef }}$ & $\pm 4,8$ & $90,4^{\mathrm{bc}}$ & $\pm 0,4$ \\
\hline $\begin{array}{c}\text { Mieszanka jęczmienia z łubinem/ } \\
\text { Mixture of barley and lupine (Ra- } \\
\text { dek/Rumba) }\end{array}$ & $86,8^{\mathrm{cd}}$ & $\pm 1,5$ & $77,0^{\mathrm{bc}}$ & $\pm 2,3$ & $66,8^{\mathrm{cd}}$ & $\pm 1,1$ & $86,7^{\mathrm{d}}$ & $\pm 1,0$ \\
\hline $\begin{array}{c}\text { Mieszanka pszenżyta z łubinem/ } \\
\text { Mixture of triticale and lupine } \\
\text { (Sopot/Rumba) }\end{array}$ & $91,6^{\mathrm{b}}$ & $\pm 1,3$ & $70,1^{\mathrm{d}}$ & $\pm 1,5$ & $64,^{2 \mathrm{de}}$ & $\pm 0,7$ & $90,8^{\mathrm{abc}}$ & $\pm 1,0$ \\
\hline $\begin{array}{c}\text { Mieszanka jęczmienia z grochem/ } \\
\text { Mixture of barley and peas (Radek/ } \\
\text { Model) }\end{array}$ & $85,5^{\mathrm{d}}$ & $\pm 0,9$ & $80,6^{\mathrm{b}}$ & $\pm 1,4$ & $68,9^{\mathrm{c}}$ & $\pm 0,9$ & $87,2^{\mathrm{d}}$ & $\pm 0,5$ \\
\hline Statystyka F/Statistics F & & & & & & & & \\
\hline Wartość $\mathrm{p} / \mathrm{p}$ - value & & & & & & & & \\
\hline
\end{tabular}

*TPD - strawność rzeczywista białka/true protein digestibility; BV - wartość biologiczna/biological value; NPU - wykorzystanie białka netto/net protein utilization; DMD - strawność suchej masy/dry matter digestibility** Wartości w kolumnach opatrzone różnymi literami różnia się istotnie przy $p \leq 0,05 /$ Values in the columns with different letters differ significantly at $p \leq 0.05$ 
współczynnikiem strawności charakteryzowało się białko ziarna pszenżyta $(\mathrm{TPD}=91,9 \%)$ i nasion łubinu wąskolistnego $(\mathrm{TPD}=90,2 \%)$ oraz mieszanki skomponowanej $\mathrm{z}$ tych komponentów $(\mathrm{TPD}=91,6 \%)$. Istotnie niższy współczynniki strawności białka wykazano $\mathrm{w}$ grupie zwierząt, którym podawano diety oparte na jecczmieniu $(\mathrm{TPD}=84,8 \%)$ i grochu $(\mathrm{TPD}=84,3 \%)$ oraz ich mieszance (TPD $=85,5 \%)$, a także mieszance jęczmienia $\mathrm{z}$ łubinem wąskolistnym $(\mathrm{TPD}=86,8 \%)$. Uwagę zwraca wysoka strawność białka łubinu wąskolistnego, uzyskana mimo dużej zawartości TDF $w$ nasionach. Wynika to prawdopodobnie z metodyki stosowanej powszechnie do oznaczania strawności białka, w której diety doświadczalne sa dietami izobiałkowymi $(9,4 \%$ białka), w związku z czym różnią się ilością badanego materiału, w zależności od zawartości w nim białka (Eggum, 1973). W przypadku diety łubinowej, udział nasion łubinu był na poziomie około $30 \%$, co $\mathrm{w}$ porównaniu $\mathrm{z}$ dietami zbożowymi, składającymi w ponad $90 \%$ z ziarna zbóż, stanowiło jej niewielką część. Ilość TDF w diecie łubinowej była zatem porównywalna do jego ilości w pozostałych dietach. Łubin wąskolistny odznaczał się najmniejszą przyswajalnością białka (64,2\%), mierzona wskaźnikiem BV. Istotnie większe wartości tego wskaźnika otrzymano dla białka grochu $(73,6 \%)$ oraz białka pszenżyta $(81,8 \%)$, a przede wszystkim jęczmienia $(92,6 \%)$. Białko jęczmienia było w takim samym stopniu przyswajalne jak białko kazeiny (91,9\%), stanowiącej białko referencyjne w grupie kontrolnej. Wartość BV jest zależna od ilości aminokwasów egzogennych w białku (Rakowska i in., 1978; Pastuszewska, 2013), stąd mała koncentracja aminokwasów siarkowych w białku łubinu oraz lizyny w białku pszenżyta jest prawdopodobnie odpowiedzialna za ich niskie wartości w niniejszych badaniach. Duża wartość odżywcza białka mieszanek jęczmienia $\mathrm{z}$ łubinem wąskolistnym lub grochem wyliczona na podstawie wskaźników chemicznych została potwierdzona $\mathrm{w}$ badaniach in vitro. Białko mieszanki jęczmienia $\mathrm{z}$ grochem było w największym stopniu przyswajalne $(80,6 \%)$, w nieco mniejszym stopniu mieszanki z łubinem wąskolistnym $(77 \%$ - różnica nieistotna), a w najmniejszym stopniu $(70 \%)$ mieszanki pszenżyta z łubinem. Wykorzystanie białka netto jest wypadkową strawności białka i jego przyswajalności, stąd spośród komponentów to zboża mają największą wartość wskaźnika NPU (powyżej 75\%), a wśród mieszanek, mieszanka jęczmienia $\mathrm{z}$ grochem $(68,9 \%)$. Na wartość NPU negatywny wpływ miała ilość włókna pokarmowego i niektórych jego składników. Istotne współczynniki korelacji $(\mathrm{p}<0,05)$ uzyskano między NPU a TDF $(r=-0,820)$, I-NSP $(r=-0,825)$, UA $(r=-0,895)$ oraz RFOs $(r=-0,840)$. Badane zboża i rośliny bobowate oraz mieszanki $\mathrm{z}$ ich udziałem różniły się także istotnie w strawności suchej masy (DMD). Jej wartość była podobnie zróżnicowana jak zawartość TDF, w zakresie od $84,2 \%$ w odniesieniu do diety jęczmiennej, do $92,5 \%$ dla diety pszenżytniej. Na stopień strawności suchej masy, decydującej o wartości energetycznej nasion bobowatych, największy wpływ ma ilość włókna, składnika paszy nietrawionego w przewodzie pokarmowym zwierząt (Pastuszewska, 2013).

Podsumowując, można stwierdzić, że mieszanki roślin bobowatych grubonasiennych ze zbożami mogą stanowić wartościowy składnik pasz dla zwierząt gospodarskich. Poprzez odpowiedni dobór komponentów można kształtować nie tylko wysokość plonu i zdrowotność mieszanek, ale także ich wartość pokarmową. Mieszanki te zazwyczaj lepiej plonują niż ich komponenty w siewie czystym (COBORU, 2017), stąd wymiernym efektem upraw mieszanych jest wyższy plon składników odżywczych, przede wszystkim białka i skrobi, z jednostki powierzchni.

\section{Wnioski}

1. Stwierdzono istotny wpływ doboru komponentów do mieszanek zbożowych z roślinami bobowatymi grubonasiennymi na ich wartość pokarmową. Udział łubinu wąskolistnego w mieszance wpłynął na poprawę zawartości białka i jego jakości, ale także na wzrost włókna pokarmowego. Odnosi się to w szczególności do mieszanki z jęczmieniem.

2. Na podstawie wskaźników chemicznych wykazano większą wartość odżywczą białka mieszanek zbóż z bobowatymi, w szczególności z grochem niż ich komponentów z siewu czystego.

3. Duża wartość pokarmowa mieszanek zbożowo - bobowatych została potwierdzona bezpośrednio na zwierzętach laboratoryjnych.

4. Mieszanka jęczmienia jarego odmiany Radek $\mathrm{z}$ grochem odmiany Model charakteryzowała się najlepszym składem chemicznym i największą wartością odżywczą białka określoną metodami in vitro i in vivo.

Badania wykonano $w$ ramach zadania 2.10, Programu Wieloletniego IHAR-PIB na lata 2015-2020, finansowane przez MRiRW. 


\section{Literatura}

AACC. (2011). American Association of Cereal Chemists, Approved Methods of Analysis, 11th Ed. St. Paul, MN. USA.

AOAC. (2007). Association of Official Analytical Chemists, Official Methods of Analysis, $18^{\text {th }}$ Ed. Gaithersburg, MD

Bach Knudsen, K. E. (2014). Fiber and nonstarch polysaccharide content and variation in common crops used in broiler diets. Poultry Sci. 93, 2380-2393.

Biel, W., Jaroszewska, A. (2016). Ocena wpływu nawozów azotowych na skład chemiczny ziarna pszenżyta jarego. Annales Universitatis Mariae Curie-Skłodowska. Sectio E, Agricultura, 71 (3), 12-25.

Boros, D., Ploch, M., Gruszecka, D. (2010). Possibility of utilization of two Aegilops sp. to enhance the nutritive value of triticale. J. Anim. Feed Sci. 19, $628-637$.

Boros, D., Fraś, A., Gołębiewska, K., Gołębiewski, D., Paczkowska, O., Wiśniewska, M. (2015). Wartość odżywcza i właściwości prozdrowotne ziarna odmian zbóż i nasion rzepaku zalecanych do uprawy w Polsce. Monografie i Rozprawy Naukowe IHAR-PIB, 49, 1-119.

Brenes, A., Jansman, A. J. M., Marquardt, R. R. (2004). Recent progress research on the effects of antinutritional factors in legume and oil seeds in monogastric animals. [In:] Recent advances of research in antinutritional factors in legume seeds and oilseeds. Proc. 4th international workshop on antinutritional factors in legume seeds and oilseeds. Toledo (Spain), EAAP Publication no 110, $195-218$.

COBORU. (2017). Wyniki doświadczeń odmianowych. Mieszanki zbożowo-bobowate jare (jęczmień, pszenżyto, groch, łubin wąskolistny). 2016, 2017 (opracował Najewski A.).

de Almeida Costa, G. E., da Silva Queiroz-Monici, K., Pissini Machado Reis, S. M., de Oliveira, A. C. (2006). Chemical composition, dietary fibre and resistant starch contents of raw and cooked pea, common bean, chickpea and lentil legumes. Food Chem. 94: 327-330.

Eggum, B. O. (1973). A study of certain factors influencing protein utilization in rats and pigs. Beretn. Report, 406. Nat. Inst. Anim. Sci. Copenhagen, 173 p.

FAO/WHO, (1965). Expert Group: Protein Requirements Report No. 37

Fraś, A., Gołębiewska, K., Gołębiewski D., Mańkowski D. R., Boros D., Szecówka P. (2016). Variability in the chemical composition of triticale grain, flour and bread. J. Cereal Sci. 71, 66-72.

Grela, E. R., Kiczorowska, B., Samolińska, W. Matras, J., Kiczorowski, P., Rybiński, W., Hanczakowska, E. (2017). Chemical composition of leguminous seeds: part Icontent of basic nutrients, amino acids, phytochemical compounds, and antioxidant activity. Eur. Food Res. Technol. 243, 1385-1395.
Hejdysz, M., Kaczmarek, S. A., Rutkowski, A. (2015). Factors affecting the nutritional value of pea (Pisum sativum) for broilers. J. Anim. Feed Sci. 24, 252-259.

Jamroz, D. (2013). Żywienie zwierząt i paszoznawstwo. Cz. 3 - Paszoznawstwo. PWN, Warszawa, wyd. 2.

Jeroch, H., Lipiec, A., Abel, H., Zentek, J., Grela, E. R., Bellof ,G. (2016). Körnerleguminosen als Futter und Nahrungsmittel. DLG-Verlag, Frankfurt am Main,

Kaczmarek, S. A., Kasprowicz-Potocka, M., Hejdysz, M., Mikuła, R., Rutkowski, A. (2014). The nutritional value of narrow-leafed lupin (Lupinus angustifolius) for broilers. J. Anim. Feed Sci. 23, 160-166.

Kakade, M. L, Rackis, J. J., McGhee, J. E., Puski, G. (1974). Determination of trypsin inhibitor activity of soy products: A collaborative analysis of an improved procedure. Cereal Chem. 51, 376- 382.

Koivunen, E., Partanen, K., Perttilä, S., Palander, S., Tuunainen, P., Valaja, J. (2016). Digestibility and energy value of pea (Pisum sativum L), faba bean (Vicia faba L) and blue lupin (narrow-leaf) (Lupinus angustifolius) seeds in broilers. Anim. Feed Sci. Technol. 218, 120-127.

Kotecki, A. (2015). Dokąd zmierza agronomia w Polsce. Fragm. Agron. 32 (4), 7-21.

Kotlarz, A., Sujak, A., Strobel, W., Grzesiak, W. (2011). Chemical composition and nutritive value of protein of the pea seeds-effect of harvesting year and variety. Veget. Crops Res. Bull. 75, 57-69.

Kowieska, A., Lubowicki, R., Jaskowska, I. (2011). Chemical composition and nutritional characteristics of several cereal grain. Acta Sci. Pol., Zootechnica 10 (2), 37-50.

Król, A., Amarowicz, R., Weidner, S. (2018). Content of phenolic compounds and antioxidant properties in seeds of sweet and bitter cultivars of lupine (Lupinus angustifolius). Natoral Product Communications 13 (10), 1341-1344.

Księżak, J., Bojarszczuk, J., Staniak, M. (2016). Evaluation of yielding of mixtures of Pisum sativum L. with Triticum aestivum L. grown in organic farming. Acta Agrobot. 69 (3), 1-12.

Lahuta, L. B., Ciak, M., Rybiński, W., Bocianowski, J., Börner ,A. (2018). Diversity of the composition and content of soluble carbohydrates in seeds of the genus Vicia (Leguminosae). Genet Resour Crop Evol 65 (2), 541-554.

Lehmann, H., Hock, A., Bergner, H. (1968). Bestimmung des N-Erhaltungsbedarfes von Albinoratten. Arch. Tierernährung 18, 280-291.

Maharjan, P., Penny, J., Partington, D. L., Panozzo, J. F., 2019. Genotype and environment effects on the chemical composition and rheological properties of peas. J. Sci. Food Agric. 99, 5409-5416.

Marchello, J. A., Dryden, F. D., Hale, W. H. (1971). Bovine serum lipids. I. The influence of added animal fat on the ration. J. Anim. Sci. 32, 1008-1015. 
Mason, V. C., Bech-Andersen, S., Rudemo, M. (1980). Hydrolysate preparation for amino acid determination in feed constituents. 8. Studies of oxidation conditions for streamlined procedures. J. Anim. Phys. Anim. Nutr. 43, 146-164.

Pastuszewska, B. (2013). Nasiona roślin strączkowych. W: Żywienie zwierząt i paszoznawstwo. Cz. 3 - Paszoznawstwo, (red. Jamroz D.), PWN, Warszawa, wyd. 2, 216-231.

Piecyk, M., Wołosiak, R., Drużyńska, B., Worobiej, E. (2012). Chemical composition and starch digestibility in flours from Polish processed legume seeds. Food Chem. 135, 1057-1064.

Price, M. L., van Scoyoc, S., Butler, L. G. (1978). A critical evaluation of the vanillin reaction as an assay for tannin in sorghum grain. J. Agric. Food Chem. 26 (5), 1214-1218.

Rakowska, M., Szkiłłądziowa, W., Kunachowicz, H. (1978). Biologiczna wartość białka żywności. WNT, Warszawa.

Scott, R. (1979). Colorimetric determination of hexuronic acids in plant materials. Analyt. Chem. 51, 936-941.

Singleton, V. L., Rossi, J. A. (1965). Colorimetry of total phenolics with phosphomolybdic-phosphotungstic acid reagents. Am. J. Enol.Vitic. 16, I44-I58.

Staniak, M., Księżak, J., Bojarszczuk, J. (2014). Mixtures of legumes with cereals as a source of feed for animals.
Organic Agriculture Towards Sustainability, Vytautas Pilipavicius, IntechOpen, Available from: https://www. intechopen.com/books/organic-agriculture-towards-sustainability/mixtures-of-legumes-with-cereals-as-asource-of-feed-for-animals

Theander, O., Westerlund, E. A. (1986). Studies on dietary fibre. 3. Improved procedures for analysis of dietary fibre. J. Agric. Food Chem. 34, 330-336.

TIBCO Software Inc. 2017. Statistica (data analysis software sys-tem), version 13. http://statistica.io

Wang, X., Warkentin, T. D., Briggs, C. J., Oomah, B. D. (1998). Total phenolics and condensed tannins in field pea (Pisum sativum L.) and grass pea (Lathyrus sativus L.). Euphytica 101, 97-102.

Winiarska-Mieczan, A. (2007). Inhibitory trypsyny z rodziny Bowmana-Birka - budowa oraz znaczenie w żywieniu ludzi i zwierząt. Medycyna Wet., 63 (3), 276-281.

Xu, B. J., Chang, S. K. C. (2007). A comparative study on phenolic profiles and antioxidant activities of legumes as affected by extraction solvents. J. Food Sci. 72 (2), 159-166.

Zhu, Y., Li, T., Fu, X., Abbasi, A. M., Zheng, B., Liu, R. H. (2015). Phenolics content, antioxidant and antiproliferative activities of dehulled highland barley (Hordeum vulgare L.). J. Funct. Foods 19, 439-450. 